\title{
Lean Bundles and Performance Outcomes in the Pharmaceutical Industry: Benchmarking a Jordanian Company and Operational Excellence International Project
}

\author{
Bashar A. Alkhalidi ${ }^{1}$ \& Ayman Bahjat Abdallah ${ }^{2}$ \\ ${ }^{1}$ School of Pharmacy, The University of Jordan, Amman, Jordan \\ ${ }^{2}$ School of Business, The University of Jordan, Amman, Jordan \\ Correspondence: Ayman Bahjat Abdallah, School of Business, The University of Jordan, Amman, Jordan, Tel: \\ 962-786-951282. E-mail: a.abdallah@ju.edu.jo
}

Received: June 29, 2018

Accepted: July 12, 2018

Online Published: July 28, 2018

doi:10.5539/mas.v12n8p90

URL: https://doi.org/10.5539/mas.v12n8p90

\begin{abstract}
This study benchmarks the implementation levels and performance outcomes of lean bundles of a Jordanian pharmaceutical manufacturing company with the results of the Operational Excellence (OPEX) model. The OPEX model is an ongoing international research project in the pharmaceutical industry. The results of the OPEX project were obtained, along with permission to use them in the present study. The same question items used in the OPEX project were used to prepare a questionnaire to collect data from the Jordanian pharmaceutical company. Fifteen managers from the Jordanian company with responsibilities related to lean management completed the questionnaire. The results demonstrated that the implementation levels of lean practices and the lean performance outcomes of the Jordanian pharmaceutical co mpany varied in comparison to the OPEX project. The overall assessment showed that the Jordanian company is excellent in the total quality management bundle (at or above the levels of the bench marked data), good in the human resource bundle (almost at the levels of the benchmarked data), acceptable in the just-in-time bundle (below the levels of the benchmarked data), and weak in the total preventive maintenance bundle (considerably below the levels of the benchmarked data). There are few benchmarking studies in the pharmaceutical industry in the area of lean management. In particular, this area is under-investigated in the developing world. The current study provides insights into the value of benchmarking key lean metrics against leading companies. This approach is expected to support pharmaceutical industry managers in the developing world to evaluate their current lean state, estimate the desired state based on the benchmarking results, and set appropriate strategies to promote lean management and operational excellence in their companies.
\end{abstract}

Keywords: lean management, lean bundles, lean operational performance, benchmarking, pharmaceutical industry, Jordan

\section{Introduction}

The pharmaceutical industry in the developing world faces many challenges, such as the pressures of rising costs coupled with low pricing policies from the authorities, along with strong competition in the markets. All these factors create the need to imp lement a system that can improve the company's performance and increase pro fits. In this context, lean management is seen as a key strategic option that can considerably improve the efficiency and effectiveness of pharmaceutical companies' operational processes, thus enhancing their competitiveness in today's globally competitive markets (Abdallah and Matsui, 2007; Phan et al., 2010; Al-Zu'bi et al., 2015; Shokri, 2017).

The pharmaceutical industry in Jordan started in the early 1960s. The industry concentrated on the production of generic drugs (patent-free medicines) and building quality into its products to have the potential for export. The industry was unable to attract foreign partnerships in its early stage due to the small size of the companies and the Jordanian population in comparison with Egypt, Syria, and Morocco (Global Research, 2007).

Today, there are 14 pharmaceutical manufacturing companies in Jordan that are active in the production of pharmaceuticals (JAPM, 2017). The pharmaceutical industry is considered to be a pioneer among the exporting sectors in Jordan; $81 \%$ of production capacity is designated for export to more than 60 countries (JAPM, 2017). 
Per the Jordan Pharmaceutical Country Profile, published by Jordan's Ministry of Health in collaboration with the World Health Organization (WHO) in 2011, Jordanian pharmaceutical production capabilities are categorized into research and development for discovering new active substances, production of pharmaceutical starting materials (APIs), production of formu lations from pharmaceutical starting material, and repackaging of fin ished dosage forms (W HO, 2011). The report further revealed that in 2008, domestic manufacturers held $33 \%$ of the market share according to the produced value.

Although lean management is widely implemented by manufacturing companies (Abu Nimeh et al., 2018; Abdallah et al., 2017; Abdallah and Matsui, 2009), it has been missed by many pharmaceutical companies in developing countries including Jordan (Shehadeh et al., 2016; Awad et al., 2016; Ayoub et al., 2017). Most of the pharmaceutical companies in the Middle East and North Africa (MENA) region focus on compliance with Current Good Manufacturing Practices (cGMP) guidelines while the operational performance of the manufacturing plants is overlooked. These companies mainly use financial performance measures, while operational measures are rarely used. Due to the scarcity of research on lean management and performance in the pharmaceutical industry in developing countries, it was necessary to initiate such research to address these shortcomings.

The driving force behind this study is the need to shed light on the concept of lean management in pharmaceutical companies in developing countries, especially in the MENA region, in order to provide the industry with a new tool to improve operations. These companies usually face problems of underutilization of capacity, low levels of technology, high scrap rates, insufficient product quality, and others (Bello-Pintado and Merino-Díaz-de-Cerio, 2013). In particular, the purpose of this study is to evaluate the levels of lean bundles and lean performance of a Jordanian pharmaceutical company. Next, the collected data is benchmarked with the results of the Operational Excellence (OPEX) model. The OPEX model is an ongoing international research project in the pharmaceutical industry in the area of lean management and operational performance, adopted from St. Gallen University, Switzerland, with permission to use its data and results. Finally, conclusions and recommendations will be derived based on the findings.

The remainder of this paper is structured as follows: section 2 presents the literature review. Section 3 presents research methodology. Section 4 presents results and discussion. Finally, section 5 presents conclusions, recommendations, and research limitations.

\section{Literature Review}

\subsection{Lean Management}

The term lean production was first used by Krafcik in 1988, as part of his study of the Toyota Production System (TPS) aimed at the elimination of waste (Krafcik, 1988). The holistic consideration of lean thinking and its principles have been successfully described by Womack et al. (1990) in the book The Machine that Changed the World. Later, a second book was published, entitled Lean Thin king, by Wo mack and Jones (1996). In this book, the authors defined the central practices which lead to lean management and provide recommendations for applying these practices in any organization.

The main principles of lean management are the identification of value for the customer, the elimination of waste, and the optimum generation of flow (Melton, 2005; Abdallah and Matsui, 2009; Saleh et al., 2017). Value definition refers to the idea that any manufacturing process is a way to deliver value to the customer, and any activity that does not add value to the customer is a waste (Womack and Jones, 1996). Waste is defined as "any human activity which absorbs resources but creates no value" (Ohno, 1988). Lean management strives to eliminate types of waste that include overproduction, waiting, transport, unnecessary motion, over-processing, defects, excessive inventory, and unused employee creativity (Liker, 2003). The optimum generation of flow refers to the idea that the production flow should be continuous, with no variation. The production line should not be stopped for machine breakdown, delay, or any other problem (Besterfield, 2014). Such lean principles might not be implemented, however, due to time constraints and concerns about the impact of such principles on regulatory compliance (Womack and Jones, 1996).

The literature dealing with lean practices indicates that different authors have different approaches to lean group concepts. For example, Womack et al. (1990) focused on the influence of specific aspects of lean management on manufacturing performance figures. Shah and Ward (2003) postulated four "bundles" of interrelated and internally consistent practices; they proposed just-in-time (JIT), total quality management (TQM), total preventive maintenance (TPM), and human resource management (HRM). Gebauer et al. (2009) concluded that JIT/continuous flow production, preventive maintenance, pull system/kanban, quick changeover techniques, cross-functional workforce, and continuous improvement programs are the most frequently included lean 
practices. Azevedo et al. (2012) used the following lean practices in their study: supplier partnership, JIT, pull flow, quality management, and customer relationships. So and Sun (2010) measured lean management in terms of supplier selection, pull production, information technology, process focus, and employee empowerment. Tortorella et al. (2017) empirically validated four bundles of lean practices, namely, elimination of waste and continuous improvement, logistics management, top management commitment, and customer-supplier relationship management. Eriksson (2010) determined the following lean practices: waste reduction, process focus, continuous improvement, customer focus, systems perspective, and cooperative relationships.

This study adopts the approach proposed by Shah and Ward (2003). Accordingly, lean management is measured using four bundles: JIT, TQM, TPM, and HRM. These four bundles were selected to benchmark lean implementation of the Jordanian pharmaceutical company with the ongoing benchmarking project at St. Gallen University, which used this approach to measure lean management in the pharmaceutical industry.

\subsection{Lean Operational Performance}

Operational performance is defined as "the output or result achieved due to unique operational capabilities" (Tan et al., 2007). It usually refers to measurable outcomes of organizational processes, such as cycle time, inventory turns, and delivery (Neely et al., 1995). In this vein, operational performance is regarded as internal or process performance (Manikas and Terry, 2009). Flynn et al. (2010) pointed out that operational performance is related to internal improvements in a firm's response to a dynamic environment with regard to its competitors and customers. Lean operational performance refers to performance outcomes achieved as a result of applying lean principles. An organization that is operationally excellent through lean implementation leads its competitors by providing the lowest cost and the highest quality to its customers. It does this by performing the right tasks, at the right time, in the most efficient manner (Abdallah et al., 2009; Sharafat et al., 2016; Al-Sa'di et al., 2017).

Chen (2008) suggested that it is necessary to choose an appropriate range of performance measures, and these measures must be balanced to ensure that one performance or set of performance dimensions is not stressed to the detriment of others. Meanwhile, Gieskes et al. (1999) suggested that performance areas must be operationalized in a way that allows performance to be adequately measured against relevant performance indicators. It is necessary to find a comprehensive tool that can measure the overall lean operational performance of pharmaceutical companies. Benchmarking data are also important, especially with regard to limited published data about developing countries. Upon literature review, this study identified only a limited nu mber of publishe d works on lean practices and associated operational outcomes at pharmaceutical companies in the developing world. Shabaninejad et al. (2014) investigated the development of an integrated performance measurement model for the pharmaceutical industry in the Iranian market. They identified 25 key performance indicators; however, their suggested indicators were not presented as a comprehensive system to measure the overall lean performance of the company.

Friedli et al. (2013) adopted an operational performance model with their research group at the Institute of Technology Management at St. Gallen University. Their model had two distinctive elements: a technical sub-system and a social system. The technical sub-system consisted of the outputs of three lean bundles: TPM, TQM, and JIT. The social system included the outputs of an HRM bundle. Likewise, Bellm (2015) investigated lean operational performance in the pharmaceutical industry in emerging markets. The study used the quantitative data from the ongoing benchmarking project at St. Gallen University.

As the objective of this study is to benchmark lean bundles and lean operational performance of one Jordanian pharmaceutical company with the ongoing benchmarking project at St. Gallen University, lean operational performance indicators were adopted from the model proposed by St. Gallen University and its benchmark data. These lean operational performance indicators included items related to JIT performance, TQM performance, TPM performance, and HRM performance.

\section{Research Methodol ogy}

\subsection{Benchmarking Model Selection}

The OPEX model was selected as a benchmarking model for this study. The model was adopted from an international research project in the pharmaceutical industry in the area of lean management and opera tional performance. The project was begun in 2004 at the Institute of Technology Management at the University of St. Gallen, Switzerland, and the Transfer Center for Technology Management at the University of St. Gallen, Switzerland (Fried li et al., 2013). The project provides participating firms the opportunity to position their plants against a broad range of pharmaceutical plants, to identify possibilities for improving lean operational performance (Gütter, 2014). Since 2008, pharmaceutical firms have been permitted to enter the continuous 
benchmarking process at any time. The OPEX database includes more than 280 pharmaceutical plants from small and medium-sized companies (Bellm, 2015).

The OPEX benchmarking model includes lean enablers and outcomes. Enablers include lean bundles of JIT, TQM, TPM, and HRM. The outcomes reflect lean operational performance indicators related to JIT performance, TQM performance, TPM performance, and HRM performance (Gütter, 2014; Bellm, 2015).

Quantitative benchmarking data from OPEX was collected from Bellm (2015) and Friedli et al. (2013).

\subsection{Measures}

The survey items were adopted from the OPEX research project. In particular, the items were adopted from Bellm (2015) and Friedli et al. (2013). In the OPEX project, each lean bundle consists of several widely cited practices in the literature. Each practice was measured using several question items. The number of items to measure each practice ranged from 3 to 10. The JIT bundle included the practices of setup time reduction, pull production, layout optimization, and planning adherence. The TQM bundle included the practices of process management, cross-functional product development, customer integration, and supplier quality management. The TPM bundle included the practices of preventive maintenance, technology assessment and usage, and housekeeping. The HRM bundle included direction setting, management commitment and company culture, employee involvement and continuous improvement, and functional integration and qualification.

Respondents were asked to indicate the degree to which the provided statements apply to their plants, using a Likert scale of 1-5 where 1 indicated not at all and 5 indicated completely.

Lean operational performance was measured using key operational performance indicators adopted from the OPEX project. The indicators are related to JIT performance, TQM performance, TPM performance, and HRM performance. Table I summarizes lean operational performance indicators of each lean bundle and their respective definitions, as adopted from Bellm (2015), and the measurement unit of each indicator.

Table 1. Performance indicators of lean bundles

\begin{tabular}{|c|c|c|c|}
\hline $\begin{array}{l}\text { Lean } \\
\text { bundle }\end{array}$ & $\begin{array}{l}\text { Performance } \\
\text { indicator }\end{array}$ & Definition & Unit \\
\hline \multirow[t]{4}{*}{ JIT } & Cycle time & $\begin{array}{l}\text { "Cycle time (from weighing to packaging). E.g. } 30 \% \text { of all products } \\
\text { have a cycle time of } 15-30 \text { days. } 70 \% \text { of all products have a cycle } \\
\text { time of more than } 30 \text { days". }\end{array}$ & $\begin{array}{l}<15 \text { days } \\
15-30 \text { days } \\
>30 \text { days }\end{array}$ \\
\hline & $\begin{array}{l}\text { Service level } \\
\text { (delivery) }\end{array}$ & $\begin{array}{l}\text { "Perfect order fulfillment (percentage of orders shipped in time from } \\
\text { your site (+/- days of the agreed shipment day) and in the right } \\
\text { quantity (+/- } 3 \% \text { of the agreed quantity) and right quality) to your } \\
\text { customer". }\end{array}$ & $\%$ \\
\hline & $\begin{array}{l}\text { Fin ished } \\
\text { goods turns }\end{array}$ & $\begin{array}{l}\text { "Annual cost of goods sold divided by the average finished goods } \\
\text { inventory". }\end{array}$ & Number \\
\hline & $\begin{array}{l}\text { Raw material } \\
\text { turns }\end{array}$ & $\begin{array}{l}\text { "Annual cost of raw materials purchased divided by the average raw } \\
\text { material inventory". }\end{array}$ & Number \\
\hline \multirow[t]{4}{*}{ TQM } & Scrap rate & $\begin{array}{l}\text { "Average difference between } 100 \% \text { and real achieved output in } \\
\text { packaging operations". }\end{array}$ & $\%$ \\
\hline & $\begin{array}{l}\text { Complaint } \\
\text { rate } \\
\text { (supplier) }\end{array}$ & $\begin{array}{l}\text { "Number of complaints as a percentage of all deliveries received } \\
\text { (from your supplier)". }\end{array}$ & $\%$ \\
\hline & $\begin{array}{l}\text { Rejected } \\
\text { batches }\end{array}$ & $\begin{array}{l}\text { "Number of rejected batches as a percentage of all batches } \\
\text { produced". }\end{array}$ & $\%$ \\
\hline & $\begin{array}{l}\text { Complaint } \\
\text { rate } \\
\text { (customer) }\end{array}$ & $\begin{array}{l}\text { "Number of justified complaints as a percentage of all customer } \\
\text { orders delivered". }\end{array}$ & $\%$ \\
\hline \multirow[t]{4}{*}{ HRM } & Training & $\begin{array}{l}\text { "Number of training days per employee (all kinds of training off and } \\
\text { on the job". }\end{array}$ & days \\
\hline & $\begin{array}{l}\text { Unskilled } \\
\text { employees }\end{array}$ & Number of unskilled employees as a percentage of all employees & $\%$ \\
\hline & Absenteeism & Average number of absented days per employee per year & days \\
\hline & Fluctuation & "Employees leaving per year your site due to terminations, expired & $\%$ \\
\hline
\end{tabular}




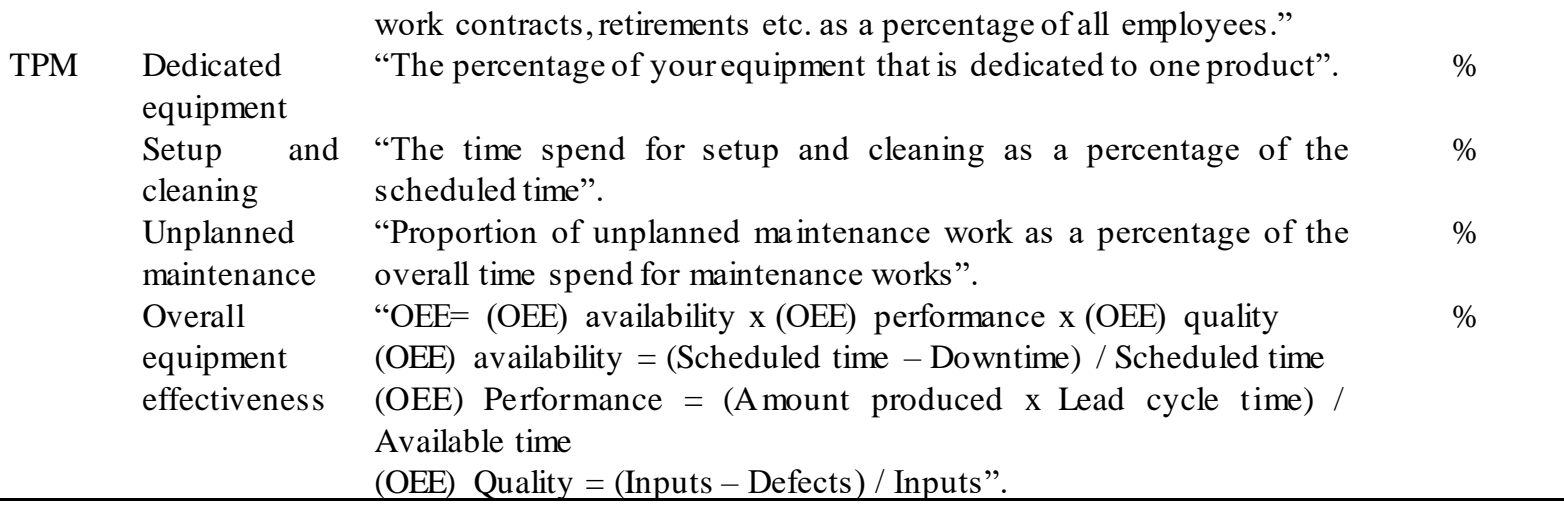

\subsection{Data Collection}

The data were collected from one Jordanian pharmaceutical company and were verified by site visits and observations at the manufacturing site. A questionnaire was prepared with constructs reflecting lean bundles and lean operational performance. The same question items used in the OPEX model were adopted for this study. The questionnaire was completed by fifteen managers, principal persons, and supervisors from various departments. In addition, interviews were conducted with the respondents to ensure that all the question items were understood and carefully answered. Respondents were encouraged to refer to the company's enterprise resource planning (ERP) system and various company units to ensure the accuracy of their responses whenever it was appropriate. The average response of the fifteen respondents was calculated for each question item and used later for benchmarking purposes.

The company selected for the survey is a local manufacturer and distributor of a broad range of pharmaceutical products. The manufacturing site has three main production plants, one for general products and the other two for cephalosporin and penicillin. The major production line at the company is solids, which represent $65.46 \%$ of the product portfolio, followed by semisolids at $26.54 \%$, liquids at $6.16 \%$, and sterile vials at $1.83 \%$.

The company has a large production staff of more than 400 full-time employees working in eight-hour day shifts. The company has many export markets in the Middle East and some European countries. The company is referred to as Jordanian Pharmaceutical Company (JPC) throughout the paper.

\subsection{Treatment of Data}

As the results of the OPEX benchmark data are reported in percentages, the data collected from the JPC was also converted to percentages. For lean constructs, the implementation level was calculated as a percentage of each practice by taking the average value of the set from the 5-point Likert scale, dividing it by 5, and multiply ing by 100. Most performance indicators were reported in percentages. In order to convert the remaining performance values into a percentage, each value was divided by its corresponding complete value in \%; for example, to convert absenteeism (in days) into a percentage, the value was divided by 365 days and multiplied by 100 to generate a percentage.

The OPEX benchmark data regarding the implementation levels of the practices of lean bundles were split into four categories for comparison purposes with JPC: top 10 refers to the top ten companies from the advanced sample; advanced refers to companies in Europe, USA, Canada, and Japan; offshore refers to multinational companies operating in emerging markets; and domestic refers to local companies from developing countries.

With regard to lean operational performance indicators, an average value for the entire OPEX data set was calculated and labeled average industry, which was compared to JPC results.

\section{Results and Discussion}

\subsection{Benchmarking JPC's Implementation Levels of Lean Practices with OPEX Data}

Table 2 shows the comparison of the implementation levels of lean practices between JPC and other sites. JPC implementation levels varied a mong practices. Practices at JPC were higher than the top-10 sample in preventive maintenance, customer integration, and pull production; in supplier quality management, employee involvement, and functional integration, JPC was at the level of the advanced sites. JPC was lower than the benchmark data in the implementation of technology assessment, housekeeping, process management, cross-functional development, setup time reduction, layout optimization, and management commitment. 
Table 2. Implementation levels of lean practices

\begin{tabular}{|c|c|c|c|c|c|}
\hline Lean practices & JPC & Top-10 & Advanced & Offshore & Domestic \\
\hline \multicolumn{6}{|l|}{ JIT } \\
\hline Setup time reduction & $58 \%$ & $69 \%$ & $63 \%$ & $60 \%$ & $66 \%$ \\
\hline Pull production & $68 \%$ & $62 \%$ & $49 \%$ & $47 \%$ & $51 \%$ \\
\hline Layout optimization & $58 \%$ & $73 \%$ & $64 \%$ & $63 \%$ & $66 \%$ \\
\hline Planning adherence & $87 \%$ & $76 \%$ & $71 \%$ & $71 \%$ & $71 \%$ \\
\hline \multicolumn{6}{|l|}{ TQM } \\
\hline Process management & $66 \%$ & $73 \%$ & $72 \%$ & $72 \%$ & $73 \%$ \\
\hline Cross-functional product development & $64 \%$ & $76 \%$ & $68 \%$ & $73 \%$ & $63 \%$ \\
\hline Customer integration & $75 \%$ & $75 \%$ & $73 \%$ & $73 \%$ & $73 \%$ \\
\hline Supplier quality management & $71 \%$ & $75 \%$ & $69 \%$ & $69 \%$ & $68 \%$ \\
\hline \multicolumn{6}{|l|}{ TPM } \\
\hline Preventive maintenance & $81 \%$ & $79 \%$ & $75 \%$ & $75 \%$ & $75 \%$ \\
\hline Technology assessment and usage & $50 \%$ & $64 \%$ & $60 \%$ & $60 \%$ & $61 \%$ \\
\hline Housekeeping & $80 \%$ & $87 \%$ & $83 \%$ & $84 \%$ & $82 \%$ \\
\hline \multicolumn{6}{|l|}{ HRM } \\
\hline Direction setting & $77 \%$ & $88 \%$ & $80 \%$ & $83 \%$ & $77 \%$ \\
\hline Management commitment \& company culture & $65 \%$ & $76 \%$ & $73 \%$ & $74 \%$ & $72 \%$ \\
\hline Employee involvement \& continuous improvement & $67 \%$ & $71 \%$ & $67 \%$ & $70 \%$ & $64 \%$ \\
\hline Functional integration \& qualification & $68 \%$ & $71 \%$ & $66 \%$ & $64 \%$ & $67 \%$ \\
\hline
\end{tabular}

* Source of Table with major data except JPC data were obtained from St. Gallen University with Permission.

\subsection{Benchmarking JPC's JIT Performance with Industry Average}

The results in Figure 1 show that cycle time at JPC from weighting to packaging is 22.5 days, which is similar to the industry average of 22.7 days. This indicates well-optimized processes with the supply chain. However, JPC's performance in the aspects related to working capital was not as expected. In raw materials turns, JPC was only 2.4 while the OPEX average was about 8 . In addition, the finished goods turns value at JPC was 3.9 turns per year compared to an average of about 16 for the industry.

JPC's performance at the service level (order fulfillment on time) was $97 \%$, which was higher than the OPEX average value of $95 \%$. This high service performance can be attributed to JPC's effective use of pull production; JPC's value was $68 \%$, as shown in Table 2, which was higher than all the other sites. Interviews with managers at JPC revealed that the company adopts both a pull system and a push system simultaneously. They use the push system for the local market, while the pull system is used for the export markets. The company's policy in the local market is to maintain a sufficient stock of products; production for export is upon request from customers. However, the usage of both pull and push systems simultaneously seems to have an effect on raw materials and fin ished goods turns. In addition, JPC showed the worst result regarding set-up time reduction, as shown in Table II; this might also have had an effect on raw materials and finished goods turns.

\subsection{Benchmarking JPC's TQM Performance with Industry Average}

The results from JPC indicate high internal performance with regard to rejected batches; it was 0 at JPC, while it was about $1 \%$ for the OPEX industry average. The scrap rate at JPC of 3.5\% was a bit higher than the OPEX average of $2.5 \%$. Zero rejected batches at JPC can be attributed to the well-implemented cGMP requirements. JPC uses well-known cGMP systems, such as annual product quality review and trend analysis, to monitor all quality-related issues. Site visits at JPC revealed that the use of measurement methods, such as statistical process control, are poorly implemented. This may explain the high scrap rate compared to the OPEX average. This is supported by the extent to which the TQM practice of process management is implemented; process manage ment includes the documentation, measurement, and improvement of processes. It was 7\% lower at JPC compared to the top 10 sites, as shown in Table 2. 


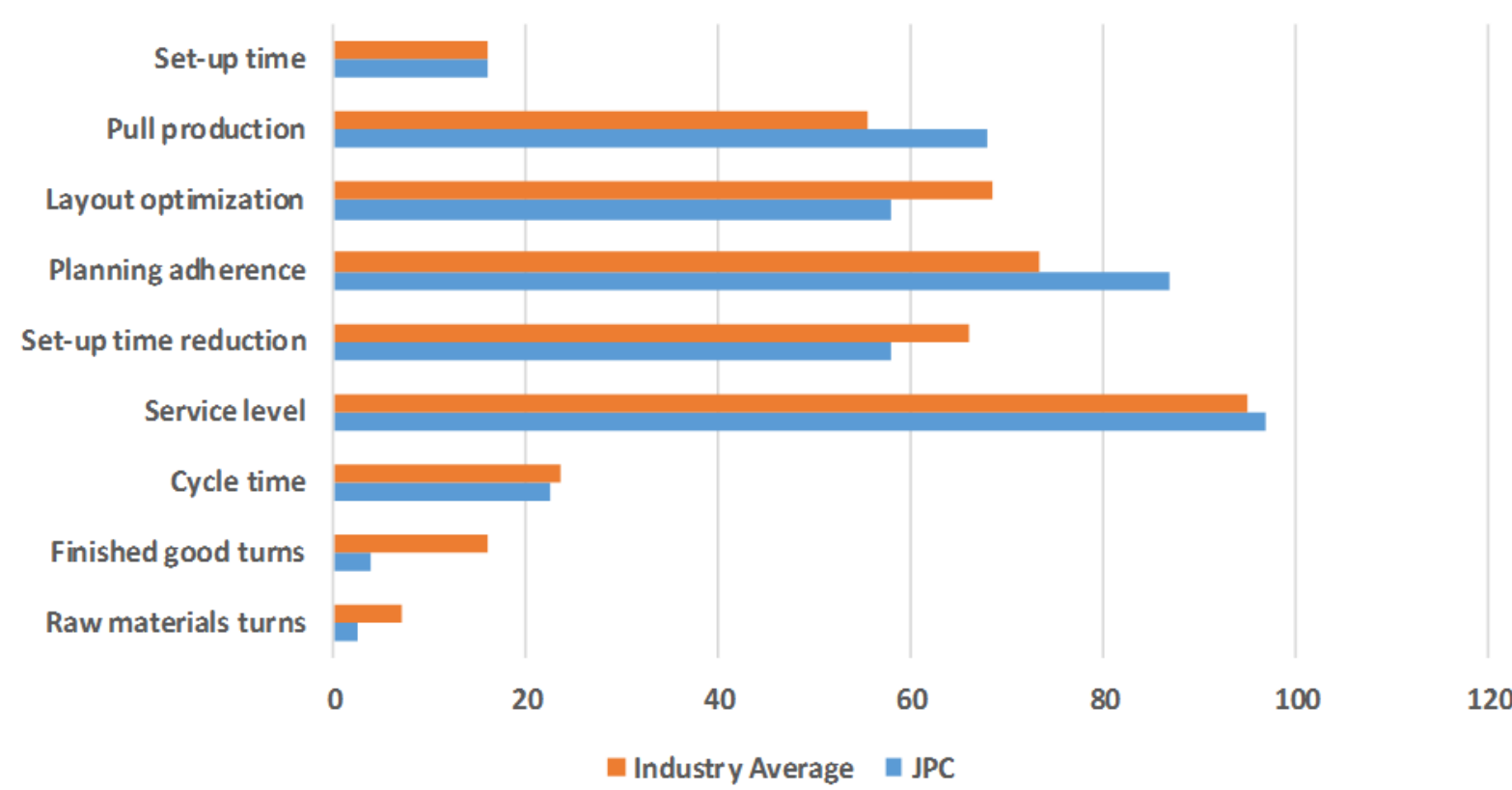

Figure 1. JIT implementation and performance at JPC compared to industry average

As for the indicators of external TQM performance, JPC showed similar high performance as the OPEX average, with regard to customer complaints $(<1 \%)$. In addition, supplier complaints were only slightly higher at JPC, with $4 \%$, as compared to the OPEX average. The high external TQM performance results at JPC can be attributed to the extensive implementation of the TQM practices of supplier quality management and customer integration; the JPC levels of implementation are very close to top-10 companies, as shown in Table 2 . Interviews with supply chain managers at JPC revealed that the company has 180 active suppliers (35\% from India, 25\% from Europe, 15\% from the Middle East, 7\% from China, and 18\% from the rest of the world). The company applies a vendor qualification system, according to cGMP requirements. For example, to approve a supplier of active pharmaceutical ingredients (API), they require a GMP certificate for the manufacturer site and a drug master file (DMF) for the API; in addition, they perform the audit at the site.

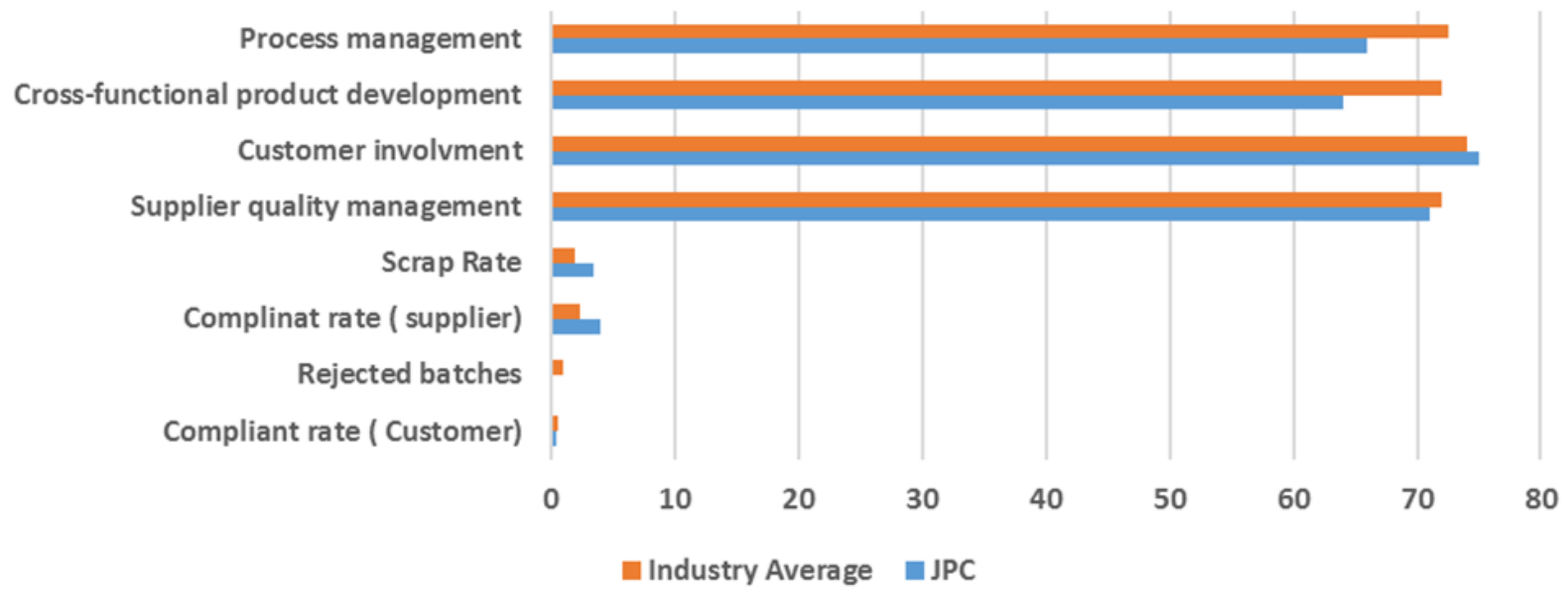

Figure 2. TQM implementation and performance at JPC compared to in dustry average

\subsection{Benchmarking JPC's HRM Performance with Industry Average}

The performance indicators of the lean HRM bundle are shown in Figure 3. Absenteeism and fluctuation are used as measures of employee satisfaction (Bellm, 2015). Absenteeism, at 2.1\%, was lower at JPC than the industry average value of 3.3\%. In fact, the low absenteeism rate at JPC might be traced to strict roles in the pharmaceutical industry in Jordan, where absenteeism may lead to loss of employ ment. Fluctuation, however, was higher at JPC, at $13 \%$, compared to the industry average of $7.5 \%$. Fluctuation seems to have a greater 
negative effect on the company, since knowledge can be lost when workers leave the company. In the Middle East region, there is a tendency for experienced workers to go work in the Gulf countries, where the salaries are much higher for the same position compared to Jordan. The generic pharmaceutical industry in that region is developing quickly, which is very attractive to Jordanian workers. Another reas on for high fluctuation at JPC could be the lack of empowerment and qualification programs. Transferring authority from supervisors to line staff is not a common practice on the shop floor, as was observed from the site visits. Employees have limited authority to act on the problems they face during production, where a wrong decision could cost an employee his job. In fact, the degree of cross-trained employees was not high at JPC. It seems that the management at the company was not previously aware of the importance of job rotation and qualification programs; a newly implemented policy at the company is aimed at improving this weak point by providing more training and rotation.

Staff qualification, represented by the portion of unskilled employees as a percentage of the total number of employees, was similar to the OPEX industry average. However, the number of training days at JPC was 2.4 days, compared to the industry average of almost 17 days. This could be attributed to company culture at JPC. Site $v$ isits revealed that executive management believes there is no place for individual involvement in any changes that are not within the regulations, so they consider following rules and regulations more important than giving suggestions or employee involvement in improvement. They feel that giving the employees freedom to implement change would negatively affect compliance with regulations. It is therefore obvious that the direction of development, orders, decisions, and new projects flow from top management to emp loye es without feedback from shop floor employees.

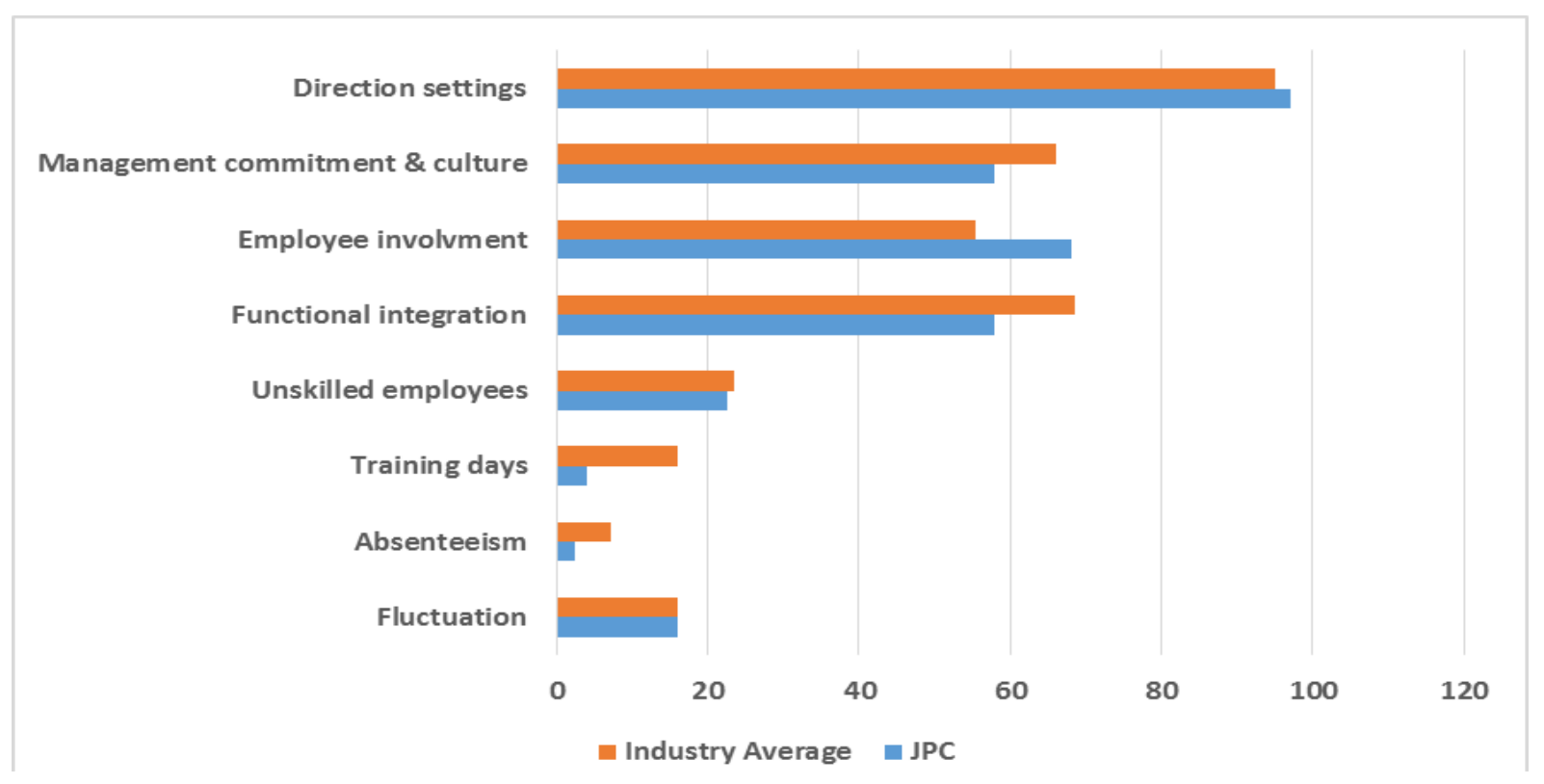

Figure 3. HRM implementation and performance at JPC compared to industry average

\subsection{Benchmarking JPC's TPM Performance with Industry Average}

The backbone of a manufacturing site is its production lines, which are dependent on machines. Thus, the main concern is to keep the machines running at full capacity during production time. Machine failu re, lower production capacity, and low product quality are issues that have been addressed in depth in the literature as the results of poor production maintenance (Ahuja and Khamba, 2008; Abdallah, 2013).

Figure 4 shows the benchmarking results of TPM implementation practices and TPM performance at JPC compared with the industry average. The overall equip ment effectiveness (OEE) level at JPC was 36\%, which is less than the industry average of $51 \%$. In addition, unplanned maintenance work at JPC represented $70 \%$ of its overall maintenance time. The percentage seems to be very high compared to $33 \%$ for the OPEX bench mark dat a. JPC $\mathrm{v}$ isits and interviews with managers revealed that the company suffered from a lack of real preventive maintenance programs. This issue is currently undergoing improvement; the implementation level at JPC, at $81 \%$, is higher than the top-10 sites (Table 2). Engineering management is serious about implementation of preventive maintenance programs and has already started training programs for production and maintenance staff, in 
addition to the performance of full maintenance programs for the machines. They are also working on autonomous maintenance by empowering shop floor employees and machine operators. The new policy at the company is to shift from reactive to proactive maintenance. JPC is still lagging in the issues of utilization of equipment and minimizing downtime. The is sue of OEE was still new to the company when they implemented a new program to measure it for all machines.

Dedicated equipment at JPC is only about $1 \%$, while it represents about $36 \%$ of the OPEX benchmark data. The dedication of equipment to certain products reduces the need for changeovers and lowers the need for full cleaning validation between different batches after line clearance. This is evident from the TPM performance indicator of set up and cleaning, which represents $25 \%$ of schedule time at JPC as compared to the OPEX average of $15 \%$. JPC's low percentage of dedicated equipment is explained by its large product portfolio, which comprises more than 200 formulations in 1554 different stock keeping units (SKUs). The level of ded icated equipment is closely linked to the type of pharmaceutical industry; in Jordan, it is mainly a generic industry.

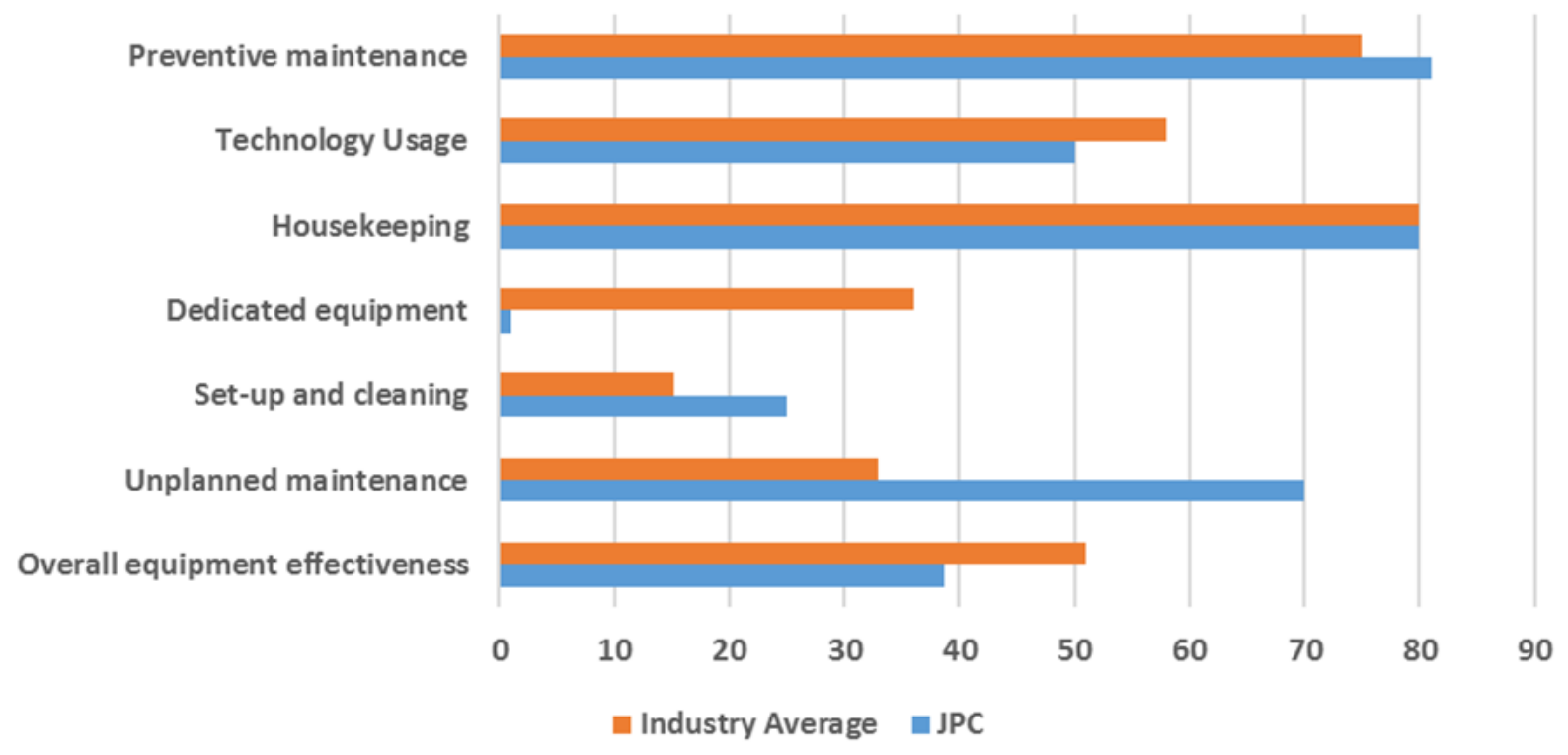

Figure 4. TPM implementation and performance at JPC compared to industry average

\section{Conclusion, Recommendations, and Limitations}

\subsection{Conclusion}

In this study, the extent to which lean practices have been implemented at one Jordanian pharmaceutical company were benchmarked with the results of the international research project in the pharmaceutical industry (OPEX). The adopted operational excellence (OPEX) benchmarking model provides a comprehensive methodology to evaluate the overall lean levels and performance of pharmaceutical manufacturing companies. The proposed model can assist pharmaceutical companies in emerging markets to evaluate their performance and develop appropriate implementation procedures for improving and enhancing operational effectiveness and efficiency. The model includes four lean bundles: JIT, TQM, TPM, and HRM. Each bundle was benchmarked in terms of the implementation levels of its main practices and the performance of the lean bundle.

The criteria shown in Table 3 were adopted in order to as sess the implementation and performance levels at JPC compared to the benchmarked data.

The proposed criteria combine the implementation and performance levels of each lean bundle in order to make an overall assessment and rating of each bundle relative to the benchmarking data. The overall assessments are based on the results of JPC regarding the practices and performance indicators of each bundle compared with the benchmarking data reported in the previous sections. In addition, site visits to JPC by the authors and interviews with managers were taken into consideration to avoid misleading conclusions. 
Table 3. Proposed criteria for rating JPC's results compared with the benchmarked data

\begin{tabular}{ll}
\hline Category of rating & \multicolumn{1}{c}{ Definition } \\
\hline Excellent & $\begin{array}{l}\text { The implementation and performance levels of the lean bundle at JPC are at or above the } \\
\text { levels of the benchmarked data. } \\
\text { The implementation and performance levels of the lean bundle at JPC are almost at the } \\
\text { levels of the benchmarked data. } \\
\text { The implementation and performance levels of the lean bundle at JPC are below the levels } \\
\text { of the benchmarked data. } \\
\text { The implementation and performance levels of the lean bundle at JPC are considerably } \\
\text { below the levels of the benchmarked data. }\end{array}$ \\
\hline
\end{tabular}

A careful as sessment reveals a rating for JPC that is close to excellent for the TQM bundle. The implementation of TQM practices at JPC was excellent with regard to customer integration and supplier quality management. Process management and cross-functional product development showed levels ranging between good and acceptable. Likewise, the TQM performance was excellent, especially given the $0 \%$ of rejected batches and customer complaint rate. In addition, good performance results were shown with regard to scrap rate and supplier complaint rate.

The overall as sessment of the HRM bundle reveals a rating close to good. The implementation level of the HRM practice of functional integration was excellent. Employee involvement showed a good implementation level. The practices of direction setting and management commit ment showed acceptable imple mentation levels. HRM performance indicators showed excellent ratings regarding three indicators: unskilled employees, absenteeis $m$, and fluctuation. However, JPC showed a weak rating regarding training days.

The overall rating of the JIT bundle is close to acceptable. The implementation levels of the JIT practices of pull production and planning adherence at JPC were excellent. However, the two other practices, setup time reduction and layout optimization, showed acceptable implementation levels. As for JIT performance, JPC showed excellent performance concerning delivery service level and good performance concerning cycle time. Nevertheless, JPC showed weak performance with regard to finished goods turns and raw materials turns.

Regarding the TPM bundle, the overall assessment of JPC tended to be weak. Although the implementation level of TPM practice of preventive maintenance was excellent, the levels of technology assessment and housekeeping were weak and acceptable, respectively. TPM performance showed an excellent rating regarding setup and cleaning. However, performance indicators of dedicated equipment, unplanned maintenance, and OEE showed weak ratings at JPC. Figure 5 summarizes the overall rating of each lean bundle.

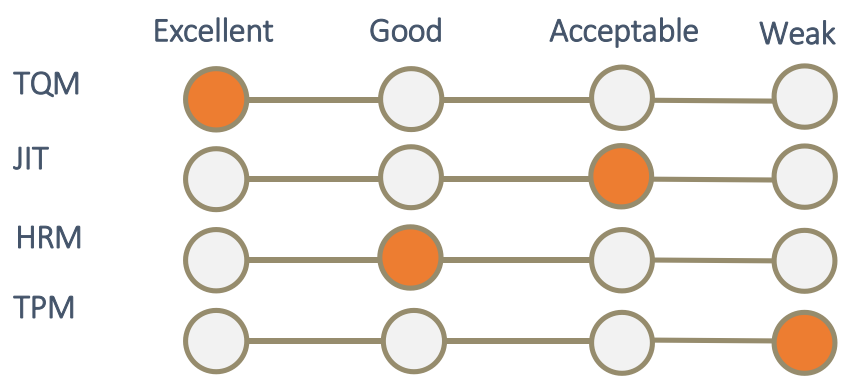

Figure 5. Overall rating of implementation levels and performance of lean bund les at JPC

\subsection{Recommendations}

With regard to TQM, it is recommended that JPC management maintain customer complaints at a low level while keeping rejected batches to zero. In addition, imp rovement plans are needed to reduce supplier co mplaints and scrap rates. With regard to JIT, it is recommended that JPC continue working on reducing cycle and setup times. In addition, considerable improvements are needed to improve performance metrics on raw material and fin ished product turns. With regard to HRM, JPC management should make an effort to diffuse the strategic direction company-wide, to positively influence the organizational culture and reflect management's commitment to lean philosophy. Training represents one major weakness at JPC; it should be given priority, as it promotes cross-functional teams and provides the basis for real improvements. Likewise, emphasis should be 
given to reducing fluctuation and increasing employee involvement. With regard to TPM, there is plenty of room for improvement by enhancing preventive maintenance programs while in itiating OEE monitoring, reducing unplanned maintenance, improving housekeeping, and increasing the qualification of the maintenance staff through training.

\subsection{Managerial Implications}

The pharmaceutical industry, like other industries, faces challenges associated with severe global competition and pressure to improve quality while reducing cost. This situation is even more evident in developing countries, where many companies struggle to sustain their market shares and improve the efficiency and effectiveness of their operations. While lean management has grown in popularity in the pharmaceutical industry in developed countries, it is still a new concept in developing countries. Managers must consider lean management as an effective competitive strategy for achieving operational excellence. Benchmarking the levels and performance outcomes of lean bundles with leading international companies enables companies in the developing world to assess their success and determine areas that should be targeted for improvement. The current benchmarking study of the pharmaceutical manufacturing company in Jordan provides insights regarding the usefulness of comparing key lean metrics against leading companies. This new approach to the pharmaceutical industry in developing countries can support senior management in adopting appropriate strategic plans to promote lean manage ment and operational excellence in their companies. In addition, the data presented in this study represent essential information in this field that can be utilized by companies to implement a lean program and steer themselves toward operational excellence, regardless of the region in which the manufacturing site is located.

\subsection{Limitations}

This study was applied to only a single pharmaceutical company in Jordan. This was due to the familiarity of this company with lean management; in addition, other companies declined to participate. Future studies are needed in developing countries with an appropriate sample size of pharmaceutical companies to obtain more generalizable results regarding lean management and enable investigation of causal relationships. Finally, only fifteen responses were received from JPC. This small number is inappropriate for performing validity and reliability analysis of the constructs. Future studies with an appropriate sample size will avoid this limitation.

\section{References}

Abdallah, A. B. (2013). The In fluence of "Soft" and "Hard" Total Quality Management (TQM) Practices on Total Productive Maintenance (TPM) in Jordanian Manufacturing Companies. International Joumal of Business and Management, 8(21), 1-13.

Abdallah, A. B., Abdullah, M. I., \& Saleh, F. I. M. (2017). The Effect of Trust with Suppliers on Hospital Supply Chain Performance: The Mediating Role of Supplier Integration. Benchmarking: An International Journal, 24(3), 694-715.

Abdallah, A. B., Phan, A. C., \& Matsui, Y. (2009). Investigating the Relationship between Strategic Manufacturing Goals and Mass Customization. The 16th International Annual European Operations Management Association (EurOMA) proceedings, Goteborg, June, 1-10.

Abdallah, A., \& Matsui, Y. (2007). Just in Time Production and Total Productive Maintenance: Their Relationship and Impact on JIT and Competitive Performances. The 9th International Decision Sciences Institute Conference proceedings, Bangkok, July, 1-10.

Abdallah, A., \& Matsui, Y. (2008). Customer Involvement, Modularization of Products, and Mass Customization: Their Relationship and Impact on Value to Customer and Competitiveness. The Third World Conference on Production and Operations Management Proceedings, Tokyo, August, 1-19.

Abdallah, A., \& Matsui, Y. (2009). The Impact of Lean Practices on Mass Customization and Competitive Performance of Mass-Customizing Plants. The 20th Annual Production and Operations Management Society (POMS) Conference proceedings, Orlando, May, 1-30.

Abu Nimeh, H., Abdallah, A. B., \& Sweis, R. (2018). Lean Supply Chain Management Practices and Performance: Empirical Evidence from Manufacturing Companies. International Journal of Supply Chain Management, 7(1), 1-15.

Ahuja, I. P. S., \& Khamba, J. S. (2008). Total Productive Maintenance: Literature Review and Direction. International Journal of Quality \& Reliability Management, 25(7), 709-756.

Al-Sa'di, A., Abdallah, A. B., \& Dahiyat, S. E. (2017). The Mediating Role of Product and Process Innovations on the Relationship between Knowledge Management and Operational Performance in Manufacturing 
Companies in Jordan. Business Process Management Journal, 23(2), 349-376.

Al-Zu'bi, Z. M. F., Tarawneh, E., Abdallah, A. B., \& Fidawi, M. (2015). Investigating Supply Chain Integration Effects on Environmental Performance in the Jordanian Food Industry. American Journal of Operations Research, 5(4), 247-257.

Awad, H., Al-Zu'bi, Z. M. F., \& Abdallah, A. B. (2016). A Quantitative Analys is of the Causes of Drug Shortages in Jordan: A Supply Chain Perspective. International Business Research, 9(6), 53-63.

Ayoub, H., Abdallah, A. B., \& Su ifan, T. (2017). The Effect of Supply Chain Integration on Technical Innovation in Jordan: The Mediating Role of Knowledge Management. Benchmarking: An International Journal, 24(3), 594-616.

Azevedo, S. G., Govindan, K., Carvalho, H., \& Cruz-Machado, V. (2012). An Integrated Model to Assess the Leanness and Agility of the Automotive Industry. Resources, Conservation and Recycling, 66(9), 85-94.

Bellm, D. (2015). Operational Excellence in the Pharmaceutical Industry - An Architecture for Emerging Markets (Unpublished doctoral dissertation). The University of St. Gallen, Switzerland. Retrieved from https://www1.unis g.ch/www/edis.nsf/SysLkpByIdentifier/4331/\$FILE/dis4331.pdf

Bello-Pintado, A., \& Merino-Díaz-de-Cerio, J. (2013). Determinants of the Use of Quality Management Practices in Latin America: The Case of Argentina and Uruguay. Total Quality Management \& Business Excellence, 24(1-2), 31-47.

Besterfield, D. (2014). Quality Improvement (9th ed.). Pearson, Es sex, UK.

Eriksson, P. E. (2010). Improving Construction Supply Chain Collaboration and Performance: A Lean Construction Pilot Project. Supply Chain Management: An International Journal, 15(5), $394-403$.

Flynn, B. B., Huo, B., \& Zhao, X. (2010). The Impact of Supply Chain Integration on Performance: A Contingency and Configuration Approach. Journal of Operations Management, 28(1), 58-71.

Friedli, T., Basu, P., Bellm, D., \& Werani, J. (2013). Leading Pharmaceutical Operational Excellence: Outstanding Practices and Cases. Springer-Verlag Berlin Heidelberg, Germany.

Friedli, T., Goetzfried, M., \& Basu, P. (2010). Analysis of the Implementation of Total Productive Maintenance, Total Quality Management, and Just-in-Time in Pharmaceutical Manufacturing. Journal of Pharmaceutical Innovation, 5(4), 181-192.

Gebauer, H., Kickuth, M., \& Friedli, T. (2009). Lean Management Practices in the Pharmaceutical Industry. International Journal of Services and Operations Manag ement, 5(4), 463-481.

Gieskes, J. F. B., Boer, H., \& Baudet, F.C.M. (1999). CI and Performance: A CUTE Approach. International Journal of Operations \& Production Management, 19(11), 1120-1137.

Global Research (2007). Jordan Pharmaceutical Sector. Retrieved May 19, 2017, from http://www.jordanecb.org/library/634448627045122500.pdf

Gütter, S. P. (2014). Lean Practices in Pharmaceutical Manufacturing - An Empirical Investigation. Unpublished doctoral dissertation, University of St.Gallen, Switzerland. Retrieved from https://www1.unis g.ch/www/edis.nsf/SysLkpByIdentifier/4276/\$FILE/dis 4276.pdf

JAPM. (2017). The Jordanian Association of Pharmaceutical Manufacturers. Retrieved July 14, 2017, from http://www.japm.com/Public/English.aspx?Lang=2\&Page_Id=385\&Menu_Parent_ID=18\&type=R

Krafcik, J. F. (1088). Triumph of the Lean Production System. Sloan Management Review, 30(1), 41-52.

Liker, J. (2003). TheToyota Way: 14 Management Principles from the World's Greatest Manufacturer. McGraw-Hill, New York, NY.

Manikas, I., \& Terry, L. (2009). A Case Study Assessment of the Operational Performance of a Multiple Fresh Produce Distribution Centre in the UK. British Food Journal, 111(5), 421-435.

Melton, T. (2005). The Benefits of Lean Manufacturing: What Lean Thinking Has to Offer the Process Industries. Chemical Engineering Research and Design, 3(6), 662-673.

Neely, A., Gregory, M., \& Platts, K. (1995). Performance Measurement System Design: A Literature Review and Research Agenda. International Journal of Operations \& Production Management, 15(4), 80-116.

Ohno, T. (1988). Toyota Production System: Beyond Large-Scale Production. Productivity Press, New York, NY.

Phan, A., Abdallah, A. B., \& Matsui, Y. (2011). Quality Management Practices and Competitive Performance: 
Empirical Evidence from Japanese Manufacturing Companies. International Journal of Production Economics, 133(2), 518-529.

Saleh, F. I. M., Sweis, R. J., Abdelqader, B. Y., Abdallah, A. B., \& Arafeh, M. (2017). The Effect of TQM Dimensions on the Performance of International Non-Governmental Organisations Operating in Jordan. International Journal of Productivity and Quality Management, 21(4), 443-459.

Shabaninejad, H., Mirsalehian, M. H., \& Mehralian, G. (2014). Development of an Integrated Performance Measurement (PM) Model for Pharmaceutical Industry. Iranian Journal of Pharmaceutical Research, 13, 207-215.

Shah, R., \& Ward, P. T. (2003). Lean Manufacturing: Context, Practice Bundles, and Performance. Journal of Operations Management, 21(2), 129-149.

Shehadeh, R. M., Al-Zu'bi, Z. M. F., Abdallah, A. B., \& Maqableh, M. (2016). Investigating Critical Factors Affecting the Operational Excellence of Service Firms in Jordan. Journal of Management Research, 8(1), $18-49$.

Shokri, A. (2017). Quantitative Analysis of Six Sig ma, Lean and Lean Six Sig ma Research Publications in Last Two Decades. International Journal of Quality \& Reliability Management, 34(5), 598-625.

Shrafat, F. D., Akhorshaideh, A., Abdallah, A. B., \&Al-Zu'bi, Z. (2016). Understanding Formality and Informality in Information System Pre-evaluation (ISIE) Process: Examining Case Research from an Actor Network Theory ANT Perspective. Journal of Management Research, 8(1), 77-109.

So, S., \& Sun, H. (2010). "Supplier Integration Strategy for Lean Manufacturing Adoption in Electronic-Enabled Supply Chains. Supply Chain Management: An International Journal, 15(6), 474-487.

Tan, K. C., Kannan, V. R., \& Narasimhan, R. (2007). The Impact of Operations Capability on Firm Performance. International Journal of Production Research, 45(21), 5135-5156.

Tortorella, G. L., Miorando, R., \& Marodin, G. (2017). Lean Supply Chain Management: Empirical Research on Practices, Contexts and Performance. International Journal of Production Economics, 193, 98-112.

WHO. (2011). World Health Organization, Jordan Pharmaceutical Country Profile. Retrieved July 23, 2017, from http://www.who.int/medicines/areas/coordination/Ghana_PSCPNarrativeQuestionnaire_03022012.pdf

Womack, J. P., \& Jones, D. T. (1996). Lean Thinking: Banish Waste and Create Wealth in Your Corporation. Simon \& Schuster, New York, NY.

Womack, J. P., Jones, D. T., \& Roos, D. (1990). The Machine That Changed the World: The Story of Lean Production. Raws on Associates, New York, NY.

\section{Copyrights}

Copyright for this article is retained by the author(s), with first publication rights granted to the journal.

This is an open-access article distributed under the terms and conditions of the Creative Commons Attribution license (http://creativecommons.org/licenses/by/4.0/). 